\title{
Importance of large colony formation in bloom-forming cyanobacteria to dominate in eutrophic ponds
}

\author{
Yoshimasa Yamamoto*, Fuh-Kwo Shiah and Yi-Lung Chen \\ Research Center for Environmental Changes, Academia Sinica, Taipei 11529, Taiwan
}

Received 5 July 2010; Accepted 11 November 2010

\begin{abstract}
The distribution of bloom-forming cyanobacteria in eutrophic to hypereutrophic ponds was studied in northern Taiwan in 2009. Eighty-four ponds were sampled in mid-summer, and the relationship between colony size and relative abundance of each cyanobacterial species was analyzed. Anabaena crassa and Cylindrospermopsis raciborskii were the dominant species in terms of frequency of appearance. The colony size of An. crassa increased significantly with its relative abundance. The relative abundance of C. raciborskii was usually below $10 \%$, and its filament length was not correlated with its relative abundance. The colonies of Microcystis aeruginosa normally consisted of several tens of cells. However, when M. aeruginosa exclusively dominated the plankton community, the average number of cells in a colony reached several hundreds. The mean filament length of Planktothricoides raciborskii significantly increased with its relative abundance. The correlations between colony size and relative abundance of the ten cyanobacterial species were significantly positive for three species, insignificantly positive for five species and insignificantly negative for two species. Given the various ecological advantages of large colonies, the results of this study may suggest that the formation of large colonies of some cyanobacterial species is important to their dominance and/or bloom formation.
\end{abstract}

Key words: Colony size / cyanobacterial blooms / filament length / nutrient concentration / relative abundance

\section{Introduction}

The formation of cyanobacterial blooms is frequently observed in eutrophic freshwater environments worldwide. Much effort has been made to investigate the ecophysiology of bloom-forming cyanobacteria, and some hypotheses concerning the mechanism of their dominance have been proposed (Hyenstrand et al., 1998; Dokulil and Teubner, 2000). High temperature seems to be the most important prerequisite condition, since bloomforming cyanobacteria generally become dominant in high-temperature seasons and most species exhibit maximum growth rates at high temperatures (Robarts and Zohary, 1987). If the environmental conditions are suited to the growth of cyanobacteria, then whether they become dominant in the water body depends on their ecological strategies, which are related to their competitive advantage over co-occurring photosynthetic species and defense mechanisms against predation by zooplankton. Heterocystous genera, such as Anabaena, Aphanizomenon and Cylindrospermopsis, can fix $\mathrm{N}_{2}$ (Adams and Duggan,

\footnotetext{
*Corresponding author: yyama@rcec.sinica.edu.tw
}

1999), and so are assumed to have an advantage over those that cannot fix $\mathrm{N}_{2}$. Even non- $\mathrm{N}_{2}$-fixing genera, such as Microcystis, can take up dissolved inorganic nitrogen more rapidly than many other species (Takamura et al., 1987). Efficient nitrogen uptake ability, together with a large capacity for phosphorus (Sbiyyaa et al., 1998), may explain why cyanobacterial blooms tend to be favored in nitrogen-limited waters (Smith and Bennett, 1999). Additionally, many cyanobacterial species produce toxic compounds that can adversely affect large filter feeders (Nogueira et al., 2004; Rohrlack et al., 2005). As is well known, large filter feeders often disappear from the water where cyanobacteria are blooming, and this phenomenon may be at least partially accounted for by the impact of such toxins (Fulton and Paerl, 1987).

The formation of large colonies is also effective in preventing cyanobacteria from being grazed by zooplankton (Jarvis et al., 1987; Yang et al., 2009). Colony formation is not only involved in defense against zooplankton grazing; some ecological advantages of cyanobacteria are strongly related to their colony morphology. Diel vertical migration or buoyancy regulation enables cyanobacteria to migrate to the optimal depth for irradiance and/or nutrients 
(Ibelings et al., 1991; Brookes and Ganf, 2001), and the velocity of their migration varies positively with colony size (Kromkamp and Walsby, 1990). The effectiveness of phosphorus uptake by large colonies has been demonstrated in Microcystis (Shen and Song, 2007), although thick diffusion boundary layers around colonies may restrict nutrient uptake from low external concentrations (Beardall et al., 2009). Moreover, large colonies are at an advantage in reducing damage from ultraviolet radiation (Sommaruga et al., 2009), although they may exhibit selfshading, restricting the absorption of photosynthetically active radiation.

Recently, Yamamoto and Shiah (2010) suggested that the growth mechanism of Microcystis aeruginosa serves to increase the number of large colonies as the bloom proceeds. Considering the ecological advantages of large colonies, as described above, the growth mechanism of $M$. aeruginosa seems reasonable to facilitate its dominance in the plankton community. This supposition leads to the hypothesis that, if the colony size of a certain cyanobacterial species is part of an ecological strategy to dominate in the water, then colony size will increase with its relative abundance in the community of photosynthetic plankters. The aim of this study was to test this hypothesis by elucidating the relationship between relative abundance of a cyanobacterial species and its mean colony size among ponds in northern Taiwan.

\section{Materials and methods}

\section{Sampling}

The study site is located in Taoyuan, northern Taiwan (Fig. 1). The climate of this area is humid subtropical. The study site includes approximately 300 freshwater ponds, most of which are used for fisheries or irrigation. The study ponds were selected depending on accessibility and the granting of permission by the pond owners to sample the pond water. Eighty-four ponds were sampled from 18 August to 4 September 2009. Samples were taken between 11:00 a.m. and 18:00 p.m. The surface water temperature was measured using a water quality checker U-52G (Horiba, Kyoto, Japan). Thereafter, $100 \mathrm{~mL}$ of surface water was collected in a polycarbonate bottle, and brought in a cool box to the laboratory. Fifty milliliters of subsamples were preserved at $-20^{\circ} \mathrm{C}$ until the concentrations of total nitrogen (TN) and total phosphorus (TP) were analyzed.

\section{Measurement of nutrient concentrations}

The TN concentration was determined as $\mathrm{NO}_{3}^{-}-\mathrm{N}$ concentration under acidic conditions using an SP-8001 spectrophotometer (Metertech Inc., Taipei, Taiwan) following hydrolysis with alkaline potassium persulfate in an autoclave at $121^{\circ} \mathrm{C}$ for $30 \mathrm{~min}$ (Crumpton et al., 1992). The TP concentration was spectrophotometrically

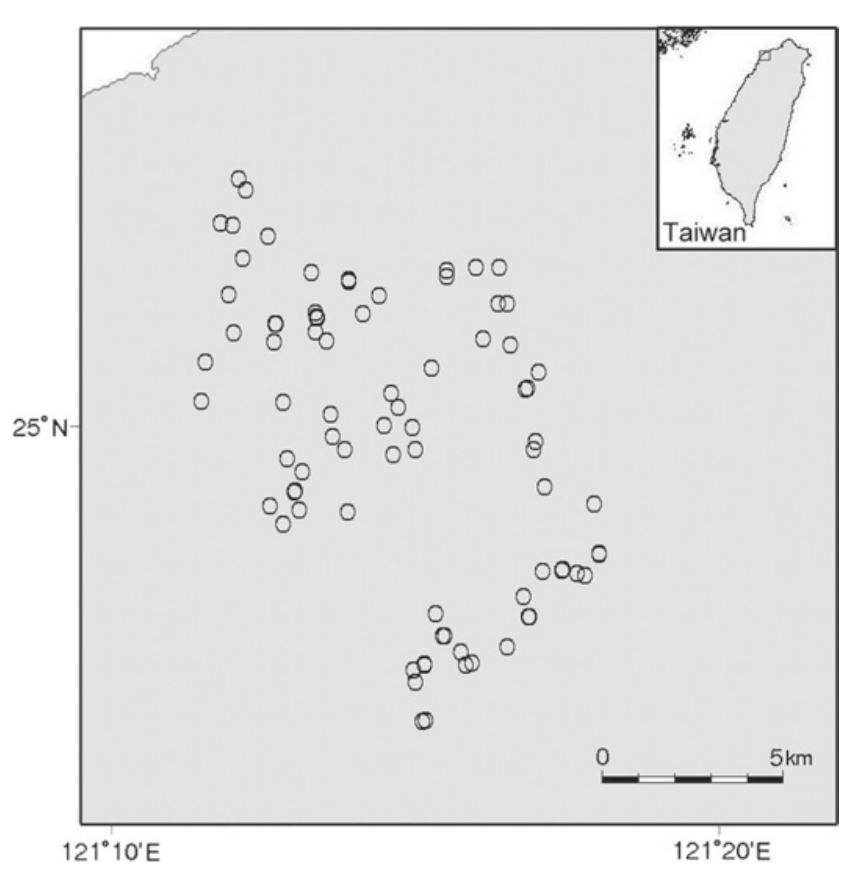

Fig. 1. Locations of sampling sites. Some points that mark locations of nearby ponds are overlapped.

measured as $\mathrm{PO}_{4}{ }^{3-}$-P concentration (Murphy and Riley, 1962) following hydrolysis with potassium persulfate in an autoclave at $121^{\circ} \mathrm{C}$ for $30 \mathrm{~min}$.

\section{Counting of photosynthetic microorganisms}

A $5 \mathrm{~mL}$ aliquot of each water sample was fixed with $50 \mu \mathrm{L}$ Lugol's solution to count the photosynthetic plankters. The species composition was observed under an inverted microscope (Axio Observer A1, Carl Zeiss, Göttingen, Germany) at $\times 200$ or $\times 400$ magnification . The population densities of the photosynthetic plankters in most of the samples were very high. Therefore, to facilitate measurement, only plankters with population densities of over 20 cells.mL ${ }^{-1}$, or at least one cell or colony in $50 \mu \mathrm{L}$ of sample water, were counted. However, in the enumeration of cyanobacterial species, the lowest measurable population density was set to 1 colony. $\mathrm{mL}^{-1}$. The mean numbers of cells in colonies of Microcystis and Anabaena were determined by the method of Yamamoto and Nakahara (2009). However, when all of the observed colonies contained easily enumerable cells - fewer than 30 - the cells were counted directly under an inverted microscope. Images of each species were captured using a digital CCD camera (AxioCam MRm, Carl Zeiss, Göttingen, Germany), and basic information that is required to calculate the biovolume of each species was extracted using AxioVision 4.7 software (Carl Zeiss, Göttingen, Germany). The cell or colony volumes of the enumerated species were calculated geometrically by assuming them to be cylindrical, spherical, ellipsoidal or some other appropriate regular shape for convenience, 
and the number of cells or colonies of each plankter was thus converted to a biovolume.

\section{Data analysis}

The relationships between relative abundance and mean colony size (number of cells in a colony or filament length), between relative abundance and nutrient (TN or $\mathrm{TP})$ concentration, and between colony size and nutrient concentration were analyzed for each species. The presence of a significant correlation was identified using Pearson's correlation.

\section{Results}

The surface water temperatures in the ponds ranged from 26.72 to $34.32{ }^{\circ} \mathrm{C}$ (data not shown). The concentrations of TN and TP were $25.5-563 \mu \mathrm{M}$ and $0.596-34.3 \mu \mathrm{M}$, respectively (data not shown). A significant positive correlation existed between TN and TP concentrations $(r=0.783, n=84, P<0.001)$.

Table 1 shows the detected cyanobacterial species and the number of ponds in which each species was detected. Fifty-nine of the studied ponds contained at least one detectable bloom-forming cyanobacterial species. The most widely found species were Anabaena crassa and Cylindrospermopsis raciborskii, followed by $M$. aeruginosa and Anabaena reniformis. The frequencies of appearance of Anabaena planctonica, Aphanizomenon flos-aquae, Arthrospira maxima and Raphidiopsis mediterranea were very low.

The relationships between colony size or filament length and relative abundance of each species are shown in Figure 2 and Table 2. The relative abundance of cyanobacteria varied largely among species and ponds. The relative abundance of An. crassa ranged from $<0.1$ to $54.6 \%$ and was not significantly correlated with colony size ( $r=0.242, n=42, P>0.05)$. However, a significant positive correlation between relative abundance and colony size $(r=0.351, n=41, P<0.05)$ was detected when an outlier (relative abundance $=54.6 \%$, cell number in a colony $=8.4$ ) was excluded from the analysis. An. planctonica and Ap. flos-aquae with large filaments dominated in different ponds; their mean filament lengths were smaller in other ponds in which their relative abundances were lower. The relative abundance of Ar. maxima was less than $2.5 \%$. Its filament length increased insignificantly with relative abundance. Despite the wide distribution of $C$. raciborskii, its relative abundance was mostly below $10 \%$. The mean filament length of C. raciborskii ranged from 22.6 to $174 \mu \mathrm{m}$ when its relative abundance was below $10 \%$; however, when its relative abundance exceeded $10 \%$, the mean filament length was substantially constant - between 88.5 and $103 \mu \mathrm{m}$. The number of cells per colony of $M$. aeruginosa was typically under 50 when its relative abundance was between $<0.1$ and $85.2 \%$; however, this value reached several hundreds when its relative
Table 1. Detected cyanobacterial species and number of ponds in which each species was detected.

\begin{tabular}{lr}
\hline Species & No. \\
\hline Anabaena crassa & 42 \\
Anabaena planctonica & 3 \\
Anabaena reniformis & 17 \\
Aphanizomenon flos-aquae & 3 \\
Arthrospira maxima & 3 \\
Cylindrospermopsis raciborskii & 35 \\
Microcystis aeruginosa & 19 \\
Microcystis wesenbergii & 7 \\
Planktothricoides raciborskii & 6 \\
Planktothrix agardhii & 14 \\
Raphidiopsis mediterranea & 1 \\
\hline
\end{tabular}

Table 2. Correlation coefficients between size of colony or filament length and relative abundance.

\begin{tabular}{lr}
\hline Species & $r$ \\
\hline Anabaena crassa & $\mathbf{0 . 3 5 1}$ \\
Anabaena planctonica & 0.991 \\
Anabaena reniformis & -0.099 \\
Aphanizomenon flos-aquae & 0.793 \\
Arthrospira maxima & 0.967 \\
Cylindrospermopsis raciborskii & 0.052 \\
Microcystis aeruginosa & $\mathbf{0 . 7 2 4}$ \\
Microcystis wesenbergii & -0.150 \\
Planktothricoides raciborskii & $\mathbf{0 . 8 7 9}$ \\
Planktothrix agardhii & 0.121 \\
\hline
\end{tabular}

Bold values are significant at the $5 \%$ level. One outlier in the data for An. crassa was excluded from the analysis.

abundance exceeded $98 \%$. The relative abundance of Planktothricoides raciborskii ranged from $<0.1$ to $29.4 \%$. The mean filament length of $P$. raciborskii increased significantly with its relative abundance. The relative abundance of Planktothrix agardhii was below 5\% except in two ponds (13.2 and 19.2\%). No significant correlation existed between relative abundance and filament length for this species. The correlations between relative abundance and colony size were insignificantly negative in An. reniformis and Microcystis wesenbergii.

The relative abundances of detected cyanobacterial species, except for Ap. flos-aquae, tended to decrease as $\mathrm{TN}$ concentration increased; a significant correlation between relative abundance and TN concentration was detected only for An. crassa (Table 3). The relative abundance of An. crassa was also negatively correlated with TP concentration (Table 3). The relationships between relative abundance and TP concentration were insignificantly negative for other species except for Ar. maxima and $M$. aeruginosa, which exhibited insignificant positive correlations. A significant negative correlation between mean colony size and $\mathrm{TN}$ concentration was observed in An. crassa (Table 4). In contrast, the mean colony size of $M$. wesenbergii was significantly positively correlated with TN concentration. No species showed a significant correlation between mean colony size and TP concentration (Table 4). 

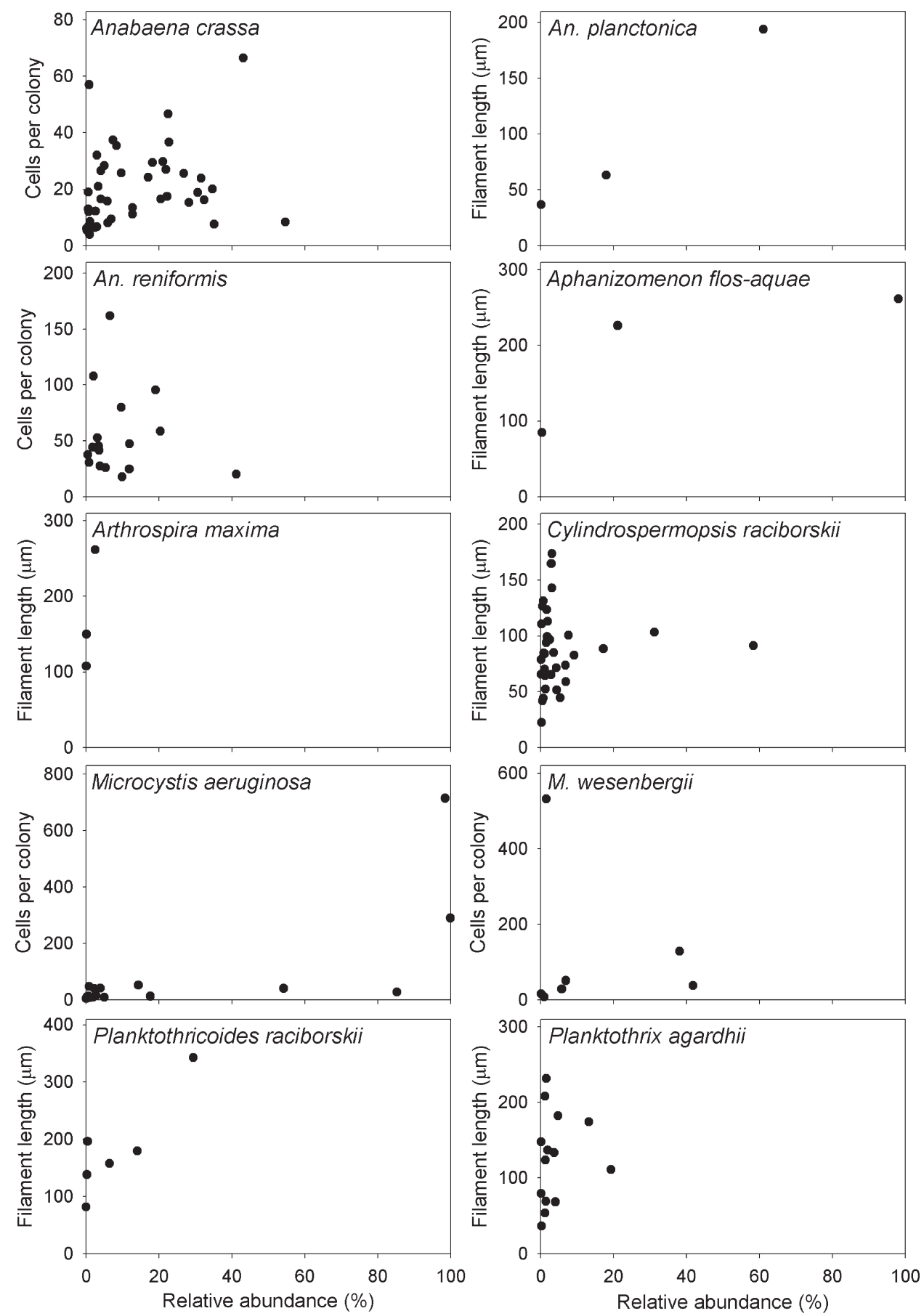

Fig. 2. Relationship between colony size or filament length and relative abundance of each cyanobacterial species.

\section{Discussion}

All study ponds can be classified as eutrophic or hypereutrophic based on TP concentration (Lampert and Sommer, 1997). Extremely high TP concentrations are probably associated with the continuous feeding of farmed fish. As expected, bloom-forming cyanobacterial species were frequently detected in many of these ponds. Since high-temperature seasons favor cyanobacterial dominance (Paerl and Huisman, 2008; Yamamoto and Nakahara,
2009), the sampling period is assumed to be the period of greatest dominance of cyanobacteria. Downing et al. (2001) reported that the relative abundance of cyanobacteria tends to increase with nutrient concentrations. However, this relationship does not always hold, especially in hypereutrophic waters (Jensen et al., 1994; Chen et al., 2003). As also observed in this study, the relative abundances of cyanobacteria in waters with very high nutrient concentrations were generally small; in such cases, diatoms and/or green algae commonly dominated. 
Table 3. Correlation coefficients between relative abundance and nutrient concentration.

\begin{tabular}{lrr}
\hline Species & \multicolumn{1}{c}{ TN } & \multicolumn{1}{c}{ TP } \\
\hline Anabaena crassa & $\mathbf{- 0 . 3 6 5}$ & $\mathbf{- 0 . 3 4 8}$ \\
Anabaena planctonica & -0.663 & -0.279 \\
Anabaena reniformis & -0.226 & -0.342 \\
Aphanizomenon flos-aquae & 0.268 & -0.501 \\
Arthrospira maxima & -0.697 & 0.514 \\
Cylindrospermopsis raciborskii & -0.236 & -0.253 \\
Microcystis aeruginosa & -0.079 & 0.126 \\
Microcystis wesenbergii & -0.050 & -0.287 \\
Planktothricoides raciborskii & -0.505 & -0.376 \\
Planktothrix agardhii & -0.294 & -0.186 \\
\hline
\end{tabular}

Bold values are significant at the $5 \%$ level.

Yamamoto and Shiah (2010) suggested that the active growth of $M$. aeruginosa occurs mainly inside colonies, and when the growth of these cells begins to be suppressed as a result of self-shading, peripheral cells separate as smaller colonies. Since the growth rate of small colonies exceeds that of peripheral cells, this growth mechanism enables a population of $M$. aeruginosa to maintain high growth activity (Yamamoto and Shiah, 2010). The present study revealed that large colonies of $M$. aeruginosa formed only when this species exclusively dominated the community of photosynthetic plankters; the colonies were not significantly large even when the cyanobacterium accounted for 54.1 or $85.2 \%$ of the total biovolume of the photosynthetic plankters. This finding implies that the formation of large colonies of $M$. aeruginosa contributes to the maintenance of its heavy bloom after it dominates in the water. The number of cells per colony of $M$. aeruginosa was in the range of several hundreds, suggesting that colony size never increases indefinitely. Although having ecological advantages, large colonies exhibit a variety of disadvantages (Beardall et al., 2009), which may determine the upper limit of effective colony size. The hypothesis about the relationship between large colony and dominance, however, seems not to hold for $M$. wesenbergii, because extremely large colonies of this species appeared even when its relative abundance was $1.5 \%$. Although the DNA sequence similarity among apparent Microcystis species, including $M$. aeruginosa and $M$. wesenbergii, has been shown to be sufficiently high to classify these species as a single species (Otsuka et al., 2001), their ecophysiological features may vary owing to morphological variation.

Our previous study showed that the pattern of seasonal change in the abundance of $P$. raciborskii (called Planktothrix raciborskii in our earlier paper) in Hirosawa-no-ike Pond was similar to that of the mean filament length, and that filament length was positively correlated with water temperature (Yamamoto and Nakahara, 2009). In the present study, the filament length of $P$. raciborskii significantly increased with its relative abundance. These results suggest that the formation of long filaments is closely related to the dominance of $P$. raciborskii.
Table 4. Correlation coefficients between colony size or filament length and nutrient concentration.

\begin{tabular}{lrr}
\hline Species & \multicolumn{1}{c}{ TN } & \multicolumn{1}{c}{ TP } \\
\hline Anabaena crassa & $\mathbf{- 0 . 3 8 5}$ & -0.264 \\
Anabaena planctonica & -0.755 & -0.402 \\
Anabaena reniformis & -0.301 & -0.213 \\
Aphanizomenon flos-aquae & -0.374 & -0.925 \\
Arthrospira maxima & -0.856 & 0.280 \\
Cylindrospermopsis raciborskii & -0.166 & -0.122 \\
Microcystis aeruginosa & 0.190 & 0.276 \\
Microcystis wesenbergii & $\mathbf{0 . 8 3 2}$ & 0.448 \\
Planktothricoides raciborskii & -0.801 & -0.674 \\
Planktothrix agardhii & -0.238 & 0.030 \\
\hline
\end{tabular}

Bold values are significant at the $5 \%$ level.

Poulíčková et al. (2004) demonstrated that although large filaments of $P$. agardhii dominated during the active growth phase, its dominance in terms of biovolume during summer was composed of smaller filaments. This finding may imply that the formation of large filaments does not significantly contribute to the dominance of $P$. agardhii, as was also weakly indicated by the present study.

The filament length of Ap. flos-aquae tended to increase with its relative abundance, despite its very low frequency of appearance. The filament length of Ap. flos-aquae tends to increase during the period of its high abundance (Yamamoto, 2009), suggesting a close relationship between the formation of large filaments and its dominance.

A noteworthy finding of this study is that $C$. raciborskii - a tropical/subtropical species whose geographically expanding coverage in temperate regions has attracted special attention (Padisák, 1997; Wood and Stirling, 2003; Hamilton et al., 2005) - is extensively distributed in northern Taiwan. C. raciborskii typically exhibits high abundance during summer months (Briand et al., 2002; Hamilton et al., 2005; Mohamed, 2007). Nevertheless, its relative abundance was generally low in this study, possibly owing to its low competitiveness despite the good adaptability (Briand et al., 2002). The mean filament lengths of $C$. raciborskii were not very large even when, exceptionally unusually, the species represented a large fraction of the phytoplankton community, suggesting that the formation of large filaments does not contribute to its dominance.

Previous field surveys have shown that the colony size of Anabaena species tends to decline with time, seemingly independently of abundance (Smith and Gilbert, 1995; Yamamoto and Nakahara, 2009). The colony size of An. crassa increased with its relative abundance, whereas that of An. reniformis exhibited an opposite trend, suggesting that the ecological roles of large colonies of these species may differ. Adjacent coils in an An. reniformis colony tightly contract around each other to form a pipelike structure. The availability of light inside such a "pipe" declines significantly as the colony size increases, which may partially explain the disadvantage of large colony formation of An. reniformis. Large filaments of An. planctonica tended to dominate in the water, 
but the actual ecological importance of large filament formation in this species remains unclear, owing to its very low frequency of appearance.

Several abiotic factors, such as nutrient concentration (Hašler et al., 2003; Kruskopf and Du Plessis, 2006), water temperature (Seki et al., 1981) and irradiance (Hašler et al., 2003), are known to influence the colony size of cyanobacteria. Furthermore, seasonal change in the colony size or filament length of a certain species may be attributable to the succession of different genotypes, given the presence of several genotypes in a population (Kardinaal et al., 2007) and the genotype-dependent range of colony size (Wilson et al., 2006). Grazing by zooplankton may further alter the distribution of sizes of cyanobacterial colonies; some species reduce cyanobacterial colony size (Burns and Xu, 1990), whereas others may lead to the dominance of large colonies by reducing the number of smaller colonies (Holm et al., 1983). These findings imply that the distribution of sizes of cyanobacterial colonies is determined by a complex interaction of abiotic and biotic factors. Nevertheless, this study demonstrated that many cyanobacterial species exhibit a positive correlation between colony/filament size and their relative abundance. Despite possible disadvantages in relation to light or nutrient acquisition, large colony/filament formation accompanies various ecological advantages (Beardall et al., 2009), which may significantly facilitate the dominance of some cyanobacterial species.

Acknowledgements. We would like to thank K.-Y. Li for his editorial assistance, as well as T. Knoy for correcting the English in the manuscript.

\section{References}

Adams D.G. and Duggan P.S., 1999. Heterocyst and akinete differentiation in cyanobacteria. New Phytol., 144, 3-33.

Beardall J., Allen D., Bragg J., Finkel Z.V., Flynn K.J., Quigg A., Rees T.A.V., Richardson A. and Raven J.A., 2009. Allometry and stoichiometry of unicellular, colonial and multicellular phytoplankton. New Phytol., 181, 295-309.

Briand J.F., Robillot C., Quiblier-Llobéras C., Humbert J.F., Couté A. and Bernard C., 2002. Environmental context of Cylindrospermopsis raciborskii (Cyanobacteria) blooms in a shallow pond in France. Water Res., 36, 3183-3192.

Brookes J.D. and Ganf G.G., 2001. Variations in the buoyancy response of Microcystis aeruginosa to nitrogen, phosphorus and light. J. Plankton Res., 23, 1399-1411.

Burns C.W. and Xu Z., 1990. Calanoid copepods feeding on algae and filamentous cyanobacteria: rates of ingestion, defaecation and effects on trichome length. J. Plankton Res., 12, 201-213.

Chen Y., Qin B., Teubner K. and Dokulil M.T., 2003. Longterm dynamics of phytoplankton assemblages: Microcystisdomination in Lake Taihu, a large shallow lake in Chuna. J. Plankton Res., 25, 445-453.

Crumpton W.G., Isenhart T.M. and Mitchell P.D., 1992. Nitrate and organic $\mathrm{N}$ analyses with second-derivative spectroscopy. Limnol. Oceanogr., 37, 907-913.
Dokulil M.T. and Teubner K., 2000. Cyanobacterial dominance in lakes. Hydrobiologia, 438, 1-12.

Downing J.A., Watson S.B. and McCauley E., 2001. Predicting cyanobacteria dominance in lakes. Can. J. Fish. Aquat. Sci., 58, 1905-1908.

Fulton R.S. III and Paerl H.W., 1987. Toxic and inhibitory effects of the blue-green alga Microcystis aeruginosa on herbivorous zooplankton. J. Plankton Res., 9, 837-855.

Hamilton P.B., Ley L.M., Dean S. and Pick F.R., 2005. The occurrence of the cyanobacterium Cylindrospermopsis raciborskii in Constance Lake: an exotic cyanoprokaryote new to Canada. Phyclogia, 44, 17-25.

Hašler P., Poulíčková A. and Vařeková Š., 2003. Comparative studies on two strains of the genus Planktothrix (Cyanophyta, Cyanoprokaryota). Algol. Stud., 108, 31-43.

Holm N.P., Ganf G.G. and Shapiro J., 1983. Feeding and assimilation rates of Daphnia pulex fed Aphanizomenon flos-aquae. Limnol. Oceanogr., 28, 677-687.

Hyenstrand P., Blomqvist P. and Pettersson A., 1998. Factors determining cyanobacterial success in aquatic systems a literature review. Arch. Hydrobiol., 51, 41-62.

Ibelings B.W., Mur L.R. and Walsby A.E., 1991. Diurnal changes in buoyancy and vertical distribution in populations of Microcystis in two shallow lakes. J. Plankton Res., 13, 419-436.

Jarvis A.C., Hart R.C. and Combrink S., 1987. Zooplankton feeding on size fractionated Microcystis colonies and Chlorella in a hypertrophic lake (Hartbeespoort Dam, South Africa): implications to resource utilization and zooplankton succession. J. Plankton Res., 9, 1231-1249.

Jensen J.P., Jeppesen E., Olrik K. and Kristensen P., 1994. Impact of nutrients and physical factors on the shift from cyanobacterial to chlorophyte dominance in shallow Danish lakes. Can. J. Fish. Aquat. Sci., 51, 16921699.

Kardinaal W.E.A., Janse I., Kamst-van Agterveld M., Meima M., Snoek J., Mur L.R., Huisman J., Zwart G. and Visser P.M., 2007. Microcystis genotype succession in relation to microcystin concentrations in freshwater lakes. Aquat. Microb. Ecol., 48, 1-12.

Kromkamp J. and Walsby A.E., 1990. A computer model of buoyancy and vertical migration in cyanobacteria. J. Plankton Res., 12, 161-183.

Kruskopf M. and Du Plessis S., 2006. Growth and filament length of the bloom forming Oscillatoria simplicissima (Oscillatoriales, Cyanophyta) in varying $\mathrm{N}$ and $\mathrm{P}$ concentrations. Hydrobiologia, 556, 357-362.

Lampert W. and Sommer U., 1997. Limnoecology: the ecology of lakes and streams, Oxford University Press, New York, $382 \mathrm{p}$.

Mohamed Z.A., 2007. First report of toxic Cylindrospermopsis raciborskii and Raphidiopsis mediterranea (Cyanoprokaryota) in Egyptian fresh waters. FEMS Microbiol. Ecol., 59, 749-761.

Murphy J.B. and Riley J.P., 1962. A modified single solution method for the determination of phosphate in natural waters. Anal. Chim. Acta, 27, 31-36.

Nogueira I.C.G., Saker M.L., Pflugmacher S., Wiegand C. and Vasconcelos V.M., 2004. Toxicity of the cyanobacterium Cylindrospermopsis raciborskii to Daphnia magna. Environ. Toxicol., 19, 453-459. 
Otsuka S., Suda S., Shibata S., Oyaizu H., Matsumoto S. and Watanabe M.M., 2001. A proposal for the unification of five species of the cyanobacterial genus Microcystis Kützing ex Lemmermann 1907 under the Rules of the Bacteriological Code. Int. J. Syst. Evol. Microbiol., 51, 873-879.

Padisák J., 1997. Cylindrospermopsis raciborskii (Woloszynska) Seenayya et Subba Raju, an expanding, highly adaptive cyanobacterium: worldwide distribution and review of its ecology. Arch. Hydrobiol., Suppl., 107, 563-593.

Paerl H.W. and Huisman J., 2008. Blooms like it hot. Science, 320, 57-58.

Poulíčková A., Hašler P. and Kitner M., 2004. Annual cycle of Planktothrix agardhii (Gom.) Anagn. \& Kom. nature population. Int. Rev. Hydrobiol., 89, 278-288.

Robarts R.D. and Zohary T., 1987. Temperature effects on photosynthetic capacity, respiration, and growth rates of bloom-forming cyanobacteria. N. Z. J. Mar. Freshwater Res., 21, 391-399.

Rohrlack T., Christoffersen K., Dittmann E., Nogueira I., Vasconcelos V. and Börner T., 2005. Ingestion of microcystins by Daphnia: Intestinal uptake and toxic effects. Limnol. Oceanogr., 50, 440-448.

Sbiyyaa B., Loudiki M. and Oudra B., 1998. Nitrogen and phosphorus intracellular capacity in storage by Microcystis aeruginosa Kütz and Synechocystis sp.: toxic cyanobacteria occasionally forming blooms in Marrakesch area (Morocco). Ann. Limnol. - Int. J. Lim., 34, 247-257.

Seki H., Ozawa H. and Ichimura S., 1981. Temperature dependence of filament length of Anabaena spiroides Klebahn var. crassa Lemm. Hydrobiologia, 83, 419-423.

Shen H. and Song L., 2007. Comparative studies on physiological responses to phosphorus in two phenotypes of bloom-forming Microcystis. Hydrobiologia, 592, 475486.
Smith A.D. and Gilbert J.J., 1995. Spatial and temporal variability in filament length of a toxic cyanobacterium (Anabaena affinis). Freshwater Biol., 33, 1-11.

Smith V.H. and Bennett S.J., 1999. Nitrogen:Phosphorus supply ratios and phytoplankton community structure in lakes. Arch. Hydrobiol., 146, 37-53.

Sommaruga R., Chen Y. and Liu Z., 2009. Multiple strategies of bloom-forming Microcystis to minimize damage by solar ultrabiolet radiation in surface waters. Microb. Ecol., 57, 667-674.

Takamura N., Iwakuma T. and Yasuno M., 1987. Uptake of ${ }^{13} \mathrm{C}$ and ${ }^{15} \mathrm{~N}$ (ammonium, nitrate and urea) by Microcystis in Lake Kasumigaura. J. Plankton Res., 9, 151-165.

Wilson A.E., Wilson W.A. and Hay M.E., 2006. Intraspecific variation in growth and morphology of the bloom-forming cyanobacteria Microcystis aeruginosa. Appl. Environ. Microbiol., 72, 7386-7389.

Wood S.A. and Stirling D.J., 2003. First identification of the cylindrospermopsin-producing cyanobacterium Cylindrospermopsis raciborskii in New Zealand. N. Z. J. Mar. Freshwater Res., 37, 821-828.

Yamamoto Y., 2009. Environmental factors that determine the occurrence and seasonal dynamics of Aphanizomenon flos-aquae. J. Limnol., 68, 122-132.

Yamamoto Y. and Nakahara H., 2009. Seasonal variations in the morphology of bloom-forming cyanobacteria in a eutrophic pond. Limnology, 10, 185-193.

Yamamoto Y. and Shiah F.K., 2010. Variation in the growth of Microcystis aeruginosa depending on colony size and position in colonies. Ann. Limnol. - Int. J. Lim., 46, 47-52.

Yang Z., Kong F., Yang Z., Zhang M., Yu Y. and Qian S., 2009. Benefits and costs of the grazer-induced colony formation in Microcystis aeruginosa. Ann. Limnol. - Int. J. Lim., 45, 203-208. 